\title{
The Role and Effect of Mass Media on Rape and Sexual Violence against Women and Girls: A case study of South Kivu in Democratic Republic of the Congo
}

\author{
Lavua Ntumba Murphy and Professor Li Zhenfang
}

School of Journalism and Communication, Huazhong University of Science and Technology, 1037 Luoyu Road, Wuhan, P.R.China

\begin{abstract}
Prevalence of grave rapes and sexual violence against women and girls in the Democratic Republic of Congo (DRC) prompted the conduction of this study. The study aimed to explore the roles and effects of mass media on rape and sexual violence against women and girls in South Kivu. One main research question, which is, what are the cognitive, affective, and behavioral effects guided data collection, analysis, presentation and discussion of research findings. The study brought forward an intensive discussion on the way mass media play different roles and exert different effects on the audiences concerning rape and sexual violence. The study used the qualitative research which involved semi-structured interview and focus group discussions to collect data from 144 participants including government officials, journalists, religious leaders and victims. The findings revealed that respondents recognized the significant roles and effects of mass media in conveying, cognitive, affective, and behavioral changes on people with regard to rape and sexual violence. On cognitive effect, the findings indicated that $72 \%$ participants believed that mass media reporting was used as a tool to help activists and governments raise awareness and implement programs on the issues of rape and sexual violence in the community. In addition, $63 \%$ participants considered that mass media have been providing methods to reduce incidents of rape and sexual violence in DRC. On affective effect, two thirds of participants considered mass media as creating awareness and instigated courage among the victims of rape and sexual violence on how to cope with the trauma. But more than half participants also suggested that mass media incorporated images that convey destructive messages, causing more trauma and disinterest among the victims. On behavioral change, $67 \%$ participants thought mass media raised awareness among the community to protect victims of rape and sexual violence against the traumas and denials., news coverage about rape and sexual violence against women were sensational, exploitative, lacking serious analysis of the prevalence hence bring no significant impact on the fight against these incidents. The study also found that victims of circumstances, women and girls are experiencing multiple pathological hurt, including, physical, psychological and social consequences. Interviewees were of the view that in some cases mass media fuels the incidents of rape and sexual violence by putting stigmas to the victims with contents they cover. As the means to combat rape and sexual violence, the study found that mass media shaped public discourse, raised sensitization, through reporting and implementing programs about issues of rape and sexual violence in DRC.
\end{abstract}

Keywords: Mass Media on Rape, Sexual Violence, female

DOI: $10.7176 / \mathrm{NMMC} / 80-07$

Publication date:May $31^{\text {st }} 2019$

\section{Introduction}

Mass media have over time increased its importance in the setting public agenda, especially on issues that draw much public attention (Hu \& Zhu, 2017; Liu, Sidhu, Beacom \& Valente, 2017). Mass media refers to organizations that use technological channels to distribute messages, attracting audience and conditioning them for repeated exposures (Potter, 2011). In this regard, Yildirim (2012) said that human life remains incomplete without mass media. The community gets information through mass media like radio, television, newspapers and internet. So, media have to cover important incidents happening in all the fields, around the world, including the incidents of rape and sexual violence. Mass media are expected to bring positive change in the society regarding rape and sexual violence. So, media persons should be cautious in covering news about incidents of rape and sexual violence against women and girls (Potter, 2012). It is addressed that how to use mass media in reporting, setting agenda, creating awareness, and to help the victims to escape from pathological outcomes (Graber \& Dunaway, 2017; Matusitz, 2017 ).

Rape and sexual violence against women and girls have attracted media attention. Media are playing a 
significant role in informing people about the incidents and their consequences as well. Recurrent acts of rape and sexual violence in DRC are caused by inter-civil wars which first occurred in the 1960s, then in the 1990s. The recent long-lasting civil war in the Democratic Republic of Congo (DRC) has been reported as an obstacle to human rights caused by the sadistic behavior of armed groups (Mukwege \& Nangini, 2009). Women and girls have been the victims as they are routinely raped and sexually abused by armed soldiers and rebels at a large scale (Farr, 2010; Hoffmann \& Vlassenroot, 2014). Persistence of rape and systemic sexual violence have been considered as common and normal acts. Therefore, DRC has been labeled as the horrible place in the world for women, and it has been appointed as the world rape capital (Brown, 2011; Grayson, 2012). Early studies have confirmed that rape and Sexual violence against women and girls, portrayed as the most significant form of violence occurring during the Congolese inter-civil wars (Bell, 2016).

Rape and other forms of sexual violence have been considered as weapon of war in DRC civil war and armed conflicts. Rape and sexual violence is used to humiliate and terrify warring tribes, their families and communities (Domingo, Wild, Brown, Jackson, \& Mosel, 2014; P. Domingo, Holmes, Menocal, \& Jones, 2013). Other authors mentioned the rape as an incredibly useful wartime weapon. Rape and Sexual violence were used to shame, demoralize and humiliate the enemy. As a result, women and girls are severely suffering (Leatherman, 2011). Equally, increased rape and sexual violence against women and girls have tactically positioned by armed groups to proclaim power and control over not only the women and girls but also men (Brown, 2011). The results from rape and sexual violence are devastating, and survivors are facing various problems, such as HIVAIDS and other genital infection diseases, unwanted pregnancies and psychological problems like fear, shame, insomnia, nightmares, isolation, homeless, spousal and community abandonment (Jones, Cooper, PreslerMarshall, \& Walker, 2014; Kalonda-Kanyama, 2010).

Observing its traumatic viral effects on women and girls resulting from rape and sexual violence, a media sustainable development program put in place to control this vast military tactic in order to protect the Congolese population from the incident (Jones et al., 2014). In order to bring a solution to this situation, several international organizations such as Amnesty International, the UN, NGOs, and mass media have been involved in reporting, propagating and dealing with the consequences of civil war for women and girls in DRC (Johnson et al., 2010). Conducting a study on the role and effects of mass media on rape and sexual violence against women and girls is pertinent at this time where women and girls in South Kivu are very depressed and have lost hope for their dignity.

This study, therefore, aimed to explore how different people perceive, the role and effects of mass media on rape and sexual violence against women and girls in DRC. The study expected to come up with concrete suggestions on how the media can be involved in the fight against rape and sexual violence by playing a significant role and bring the desired impact on the issue.

\section{South Kivu}

The province of South Kivu is the study area of this study. The region is found in the South-East of the former Kivu- Maniema in the Democratic Republic of Congo, covering an area of 64,915 km2 just over one-quarter of the former Kivu-Maniema province which had 256,805 km. The province is divided into three demographic areas such as a high-density population, area, including Idjwi, Kabare, Walungu and Uvira territories, an area of a medium-density population having Kalehe, Mwenga and Fizi territories and an area of low-density population, parallel to the Shabunda territory. The people of South Kivu are mostly farmers and those who are of Rwandan ancestry raise livestock (Ohambe, Galloy, \& Sow, 2004).

The Kivu regions have a long history of occupations of colonial and other external armed forces, and intertribal fighting. Following the Rwandan genocide in 1994, at least one million people fled to Eastern Zaire (today's Democratic Republic of Congo (DRC) (Elbert et al., 2013). In reaction to the creation of political and military organizations in Rwandan refugee camps in the Kivu provinces close to the Rwandan borders, Rwandan and Ugandan armies entered the DRC in November 1996 along with, and in support of, Laurent Desirée Kabila, launching the First Congo War, which formally ended in 1998. The Second Congo War, also known as Africa's Great War, waged from August 1998 to December 2002. This war formally brought to an end with the signing of the Lusaka Peace Accord in 1999. In 2000s, the UN mission, Mission de l'Organisation des Nations Unies en République démocratique du Congo (MONUC), deployed to the DRC. 


\section{Theoretical Review}

\subsection{Defining Mass Media}

Mass Media are instruments of social, economic and political development of any nation, it can influence people's perception and behavior in several important contexts and may serve as a potent policy instrument with its potential of spreading information and awareness (Bhattacharya, 2016). The communication refers to information transmission channels to achieve wider coverage in society (McQuail, 1994; Lee, 2009; Schäfer, 2011; Olsen \& Osmundsen, 2017). Mass communication scholars played a role of surveillance, interpretation, socialization, and entertainment.

Mass media its totality refer to communication devices, used to communicate and interact with a large number of people at different times. Mass media is categorized into three main types namely print media, Electronic, and New Age Media. Print Media includes Newspapers, Magazines, Booklets, Brochures, and Billboards. Electronic Media includes television and radio while New Age Media consists of Mobile phones, Computer, internet, and electronic books. Providing an important role disseminating information in other forms, mass media are supposed to act professionally and neutral in print or televisions. As a matter of knowledge in human awareness, mass media can be constructive, reconstructive in peace process. Beth (2007) defined mass media as any medium used to transmit mass communication. Recently mass media are clearly defined and comprised of eight industries; Books, Newspapers, Magazines, and Recordings, Radio, Movies, Television, and The Internet.

Different scholars have defined mass media, as basically aim for transmission and dissemination information through different channels. Based on the specific purpose, this study came up with the following working definition of mass media. "Mass media refers to all forms of communication such as print, television, radio and or online media which are used to shape, form a large number of people and transmit information to the wider coverage in the society".

\subsection{The Dependency Theory of Mass Media Effect}

Dependency theory of mass media has been widely explained by different authors in different contexts. BallRokeach and DeFleur (1976) conducted a study on Dependency Theory of mass media where they found that the tripartite audience-media-society relationship directly determines many of the effects that media have on people and society. An investigation about various aspects of audience-media-society relationships with the existence of a dependence of audiences on mass media information resources individuals or societies found to be the focus of mass media dependency theory. The implication for focus (audience-media-society relationships) is that the intention of audience dependence on media information is a key variable in understanding when and why media messages adjust audience beliefs, feelings, or behavior. The dependency theory assumes that society is depending on media especially when there exist social changes, conflicts, violence and or any other incidences happening in society.

Likewise, Puiu, Sablin, Georgieva \& Bykov (2015) assumed that when societies grow more complex, and as the quality of media technology improves, media continuously take on more and more unique information functions including information gathering, processing, and delivery.

Moreover, (Ball-Rokeach \& DeFleur, 1976; Jackob, 2010) suggested that the dependency theory differentiates mass media effects could influence society as well as media by putting emphasis on three types of effects: cognitive, affective and behavioral. It is substantial that mass media messages must achieve a broad range of cognitive, affective, and behavioral effects. The explanations of how Dependency theory portrays certain types of effects are illustrated in the figure 1 below. 


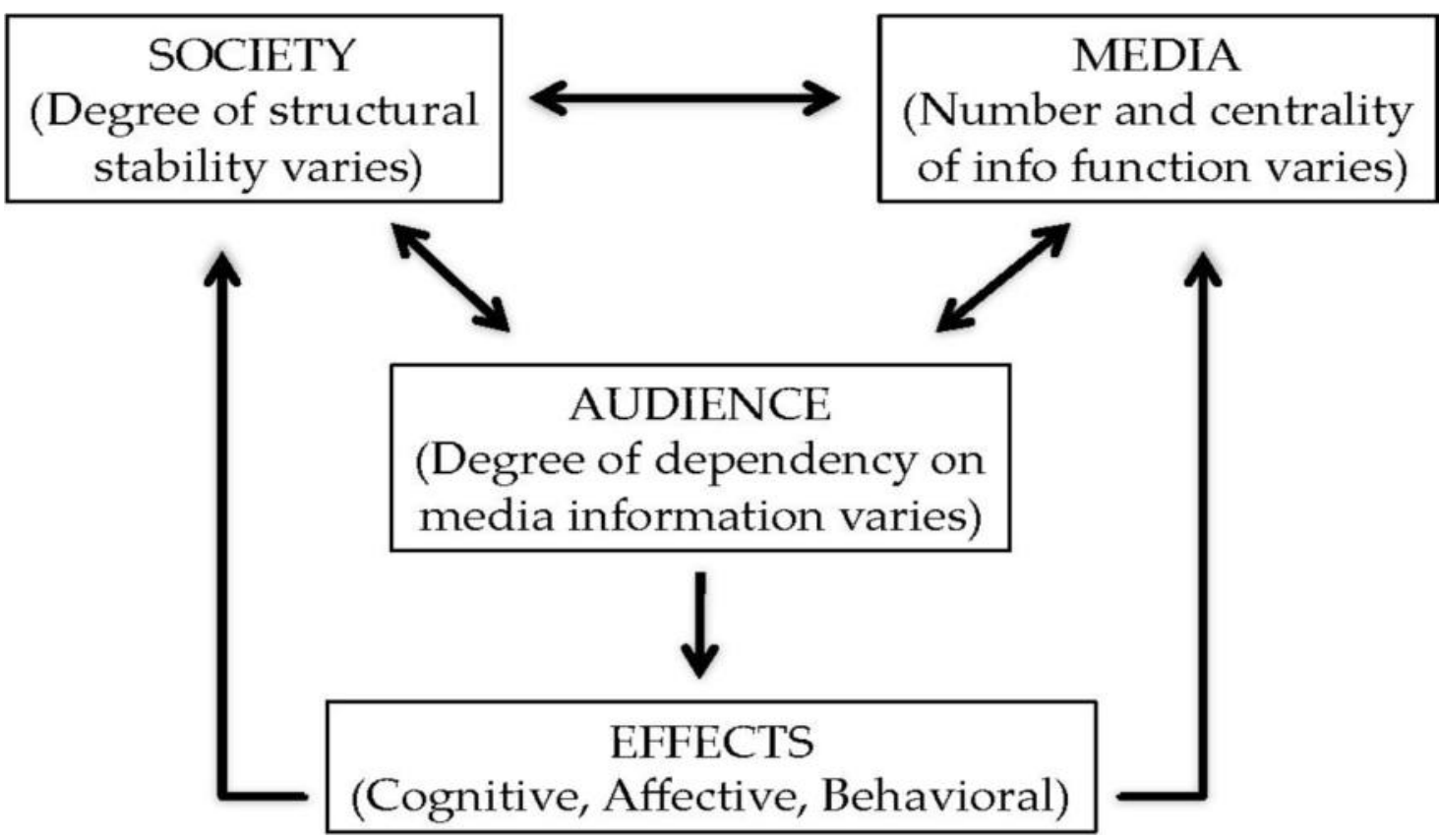

Figure 1: Society, Media, and Audience: Reciprocal Relationships extracted from (Ball-Rokeach \& DeFleur, 1976).

The above figure shows the specific kinds of cognitive, affective, and behavioral changes in people that brought about by the mass media because of individual and societal dependence on their information resources. Based on this information provided in figure 1, the theory suggests, the audiences become dependent on the media because of their need to obtain information for making decisions. The need for information originates from some fundamental items such as television, radio, prints, and online media. The audiences need to understand the social environment, effective action, and the meaning of rape and sexual violence against women and girls in order for them to escape the consequences.

Furthermore, the other cognitive effect of media happens when the attitudes of individuals are under the influence of media, because of their dependency to information resources of media for facing the variant consequences they live with. The new idea of people about social and environmental problems (rape and sexual violence against victims), is an important issue, which shows that the media is an effective factor in creating or changing special conception or attitude in general public. The hypotheses of this theory assume that the degree of public dependency on media has a direct positive correlation with the ability of the media to meet the individual's needs as much as possible. Therefore, the individual or the community will rely heavily on the medium to meet their needs and achieve its objectives.

On similar investigation, Ball-Rokeach and DeFleur (1976) found that Media Dependency theory put forward the public's dependency on media, as it distinguished the application of the influence of traditional media on recipients. The idea is based on the theory assumes that people in modern society rely on the media to understand the world around them. In addition, the media controls three types of information sources: collection, coordination, and revision. The mass media's influential role advanced through media dependency theory, which posits a structural dependency between mass media, audiences and social entities.

Shapiro and Chock (2004), described that the Dependency theory normally increased when media structures serve many distinctive and fundamental information functions. In this regard, that potential will further be increased when there is a high degree of structural instability in society due to conflict and change. 
McCombs and Shaw (1972) maintained that the effect of media use, is cognitive rather than persuasive (informing, giving both sides of an issue, and seeking to persuade individuals in the audience of one position). In that case, the media become the main suppliers of information and images about events and people outside our immediate environment. Iyengar (1991) insisted that, by promoting the various aspects of social reality, the media also influence individuals' judgments about how to deal with important social problems.

According to Patwardhan and Ramaprasad (2005), behavioral change and consistency in the media use can give clues about what influences the communication process and how that process, in turn, influence use.

McLeod, et al. (1991) explained that media influences and media effects research, should identify psychological processes that, may be triggered by the media messages and that, may direct individuals' judgment, media effects, theories are ultimately concerned with the media's impact on the behavioral effect.

Loges (1994) found that the intensity and scope of the media system and dependency relations positively related to perceptions of threats in the environment. (Waring, 1996; Merskin, 1999) tested that, the conceptualization of media as society's primary information systems and the links between individual and the social structure.

Ball-Rokeach et al. (1984) indicated that, although media exposure is predictive of effect on the target attitudes and behaviors, the observed effects are strongest for those individuals whose dependencies are more intense and linked to the message content.

Based on the literature review, many scholars talked about the dependency theory of mass media effect, but nothing existed about rape and sexual violence. In order to reduce this phenomenon of rape and sexual violence, there is a need that dependency theory of mass media effect brings in valuable stances that considered in the fight against sexual violence and rape. Media is able to capture the attention of the audience who has total dependence on media, to have knowledge of the role and the effects of mass media. Indeed, the media brings an awakening of consciousness on certain social problems, in order to prevent the consequences that, the society facing in their daily lives on rape and sexual violence against women and girls. However, though previous studies have demonstrated the societal system, media system, and audience relationship, the nature of media influence under this study shall be determined by the interactions among the four avenues, societal system, political system, media system, and audience.

Generally, from the authors' arguments, Dependency theory postulates that the impact of media messages is contingent upon the level of audience dependency on media information resources. In this endeavor, the higher of dependency, the greater of likelihood of media information influence on people's cognition, affective and behavioral change. Further, from the dependency side, the main idea of media dependency theory is a public dependency on media to get their desired information about rape and sexual violence. In fact, media is trying to create public dependency on media by creating need, interest and public personal motivation towards the social phenomenon, the role and effects of mass media in the fight against rape and sexual violence against women and girls in DRC, has not, well discussed in the literature.

Moreover, the connection between the Dependency theory of mass media effect and our research is clear. The theory focused on the audience and society which their strongly rely on media that brought the cognitive effect, affective and behavioral change. Rape and sexual violence are incidents that are at the root of the destruction of women and girls in the Democratic Republic of Congo precisely in South Kivu that need immediate attention of the media. It is worth mentioning that the theory of media dependence to identify some sensitive issues to our research as it finally contributes to illuminating the shadow waves in the collection of data from our investigation. In fact, this theory has opened our minds to how to categorize the opinions of our research based on the four interactions among the societal system, political system, media system, and audience. The notion of audience dependency on the media emerges from an interpretation of the three relationships.

\subsection{Role of the Mass Media}

Mass media plays as eyes and arms of society play crucial roles in making sure that society informed about pertinent issues happening in society. The prominent roles of mass include awareness creation, reporting and empowering meaningful stories as propagated by the framework of this study. Apparently, civil wars, rape and Sexual violence committed in any forms in different countries have attracted the concerns of mass media to step in and play an important role in propagating against its viral effects (Schultz, 2000; Carll, 2005; Akinwole \& 
Omoera, 2013; Armstrong \& Mahone, 2017). Mass media can reduce or accelerate the magnitude of civil war, rape and sexual violence if they act unprofessionally in reporting (writing or broadcasting) incidents, which have no clear investigation. Mass media compels reporters and journalists to act professional and inform the public about the significant impact of civil wars, rape and sexual violence (Egbo, 2012; Assault, 2013). Consequently, this means that the mass media play a significant role in creating awareness to the community about rape and sexual violence and its impacts so that the community takes immediate effect.

Mass media provide insights about the prevailing trends and analyze the recent major news about rape and sexual violence, providing resources to keenly report on civil wars, rape and sexual violence observing principles of sensitivity and accuracy. Reporters possess sources of data and evidence as background for new stories. They are capable of providing contacts for local government, central government or state, politicians, NGOs and other national experts on sexual violence.

Mass media, including print, television, radio, and online media coverage shapes the public agenda for policy-making processes and so, resorts to conduct a wider coverage and report the most pressing issues in the society (Scheufele \& Tewksbury, 2007; Soroka et al., 2012). Mass media also frames the conditions that policy discussions and decisions should base (Iyengar, 1991; Entman, 1993; Mejia, Cheyne \& Dorfman, 2012). In relation to rape and sexual violence, mass media coverage shapes the people's perceptions and feelings on the issue and informs the community about how to go about (McCombs \& Reynolds, 2009; Gregoriou \& O'Hara, 2012).

The valuable role of mass media is located in the formation of reality on a peace process, in conflict resolution (peace process). The peace process in conflict resolution defined as the multidimensional methods, including economy, politics, and security, in order the conflict can be resolved without any violence. Otherwise, the deconstructive role of mass media can be indicated by the news content causing a probability of violent reaction among the different actors (Imtihani, 2014).

In general, mass media is a means to deliver information from a source of information (communicator) to the recipient information (communicants). Televisions and print media, and social media takes another rounded shape of mass media which are used as the fastest way to convey information to a large number of people within a very short time and efficiently. Social media refers to a set of online tools that are designed for and centered on social interaction (Bertot, Jaeger, \& Hansen, 2012; Hansen, Shneiderman, \& Smith, 2010; Paul, Singh, \& John, 2013; Porter, 2008; Tepper, 2003). Mass media generally plays a significant role in bringing awareness to the community about anything bad or good happening in between (Graber \& Dunaway, 2017).

According to WHO (2009), mass media with television, radio, the Internet, newspapers, magazines, and other printed publications have a significant role to reach a wide range of people and effect change within society. Government has been using mass media to create public awareness and challenge gender norms and attitudes of the woman and society about rape and sexual violence and to prevent it. Mass media aim to increase knowledge, challenge attitudes and modify behavior. Their intervention in reporting cases of rape and sexual violence can also alter social norms and values (e.g. the belief that masculinity is associated with aggression) through public discussion and social interaction.

Media campaigns have proven successful in increasing knowledge of intimate partner violence and influencing attitudes towards gender norms. I summarize mass media play a significant role in producing imitations and creating awareness as described in the following paragraphs.

\subsection{The mass media effect on the audience}

The term "mass media effects" continues to be used broadly, despite the fact that many media scholars struggle with the term 'effect. According to, Wright (1986) it is evident that we speak of the 'effects' of mass communication as a convenient expression. Morley (1992) said that '“effects' is thus a shorthand and inadequate way of marking the point where audiences differentiate read and make sense of messages". Traudt (2005) argued that "the word effect is something of a misnomer, used by many because of its economy and convenience as a label encompassing a complex and varied field of theory and research'.

Bryant and Zillmann, (2009) put forward that media effects refer to the social or psychological changes that occur in consumers of the media message systems in their social milieu or cultural values as a result of being exposed to processing or acting on those mediated messages. Likewise, McQuail (2010) defined mass media effect as the consequences or outcomes of the working of or exposure to mass media whether or not intended. Potter (2011) accentuated that, mass media effect is a change in an outcome within a person, a social entity that is due to mass media influence following exposure to a mass media message with series of messages. In this case, 
rape and sexual violence against women and girls is the most pressing issue in the DRC Congo, which ultimately requires the attention of the mass media.

Media research in recent decades has shown that, media influence attitudes less directly than in a roundabout way, treating people as beings whose ideas their social environment shapes. People adjust their thinking and behavior in this social environment, which was created by ideas precisely as Walter (1992) portrayed the phenomenon, that it is through this roundabout way that the media have an effect. Given this situation, it is hardly surprising that many think it will never be possible to study the effect of the media. The effects of media messages flow back to influence people or a victim's of rape and sexual violence need a psychological and social characteristics. Moreover, in some cases, they relaxed to change the nature of the societal system itself. Behavioral alteration effects, for example, in some instances may take the form of massive protest, which not only gets people involved in producing a new series of events covered by the media, but may also increase the level of societal conflict, modified societal norms, or create new social groups.

This series of events, in turn, can force changes in the nature of the relationships between the sociocultural system and the media system, such as the passing of new laws designed to change the media is operating policies. We urge our reflection farther to wonder what it is necessary to retain all these studies on the role and the effect of mass media. "It is doubtless early, in a domain in so fast evolution, to make an assessment of available knowledge's Dayan, (1992). The author also, recognizes that "the studies of reception offer a denial to the speeches which presented this spectator as passive, as immature and as eternally in search of protection. This study allowed, and according to him, to confirm the hypothesis of the limited effects and "the sovereignty of the use which the receivers reserve for the media, Dayan (1992).

According to Meunier and Peraya (2010), the studies on the media distribute in three general domains, worth knowing (namely): the studies of the public, the studies of the contents and the studies of the effects, "in every case, the attention and the interest refer finally on the effects, direct or indirect, Meunier and Peraya, (1993). In addition, in these effects, we know that " the idea of a receiver acting on the message and proceeding to filter of its contents establishes a rather new sociological problem and certainly very rich today, Bühler (1974).

Generally, the literature has demonstrated useful information regarding mass media effect. The provided information indeed fitting with the current study because mass media is expected to play a significant role and bring desirable effects to the community regarding rape and sexual violence. Besides, the mass media effect is valid since they make information available to more people more quickly, and enable individuals to spread their innovative ideas much further than they would have been if there were no mass media. In this regard, covering and reporting of issues of rape and sexual violence performed in professional manner personnel to avoid accelerating the incidents and cause more problems to the victims and the vulnerable societies.

2.4.1 Cognitive EffectsThe cognitive effect is best described by the ambiguity of information arising from the occurrence of a particular incidence in society. In this respect, the conception and determination of ambiguity serve as the first example of a cognitive alteration effect, which is particularly likely to receive the attention of investigators working from a dependency theory. Accordingly, ambiguity can occur either due to society's lack of enough information to understand the meaning of an event, or because there is inadequate information to govern numerous possible explanations of an event (Ball-Rokeach \& DeFleur, 1976).

The situations where the initial information gathered and delivered by the media is incomplete, feelings of ambiguity created, thus audience becomes aware that an event has occurred, but they fail to know what it means or how to interpret it. In such situation more information is undoubtedly, be required in attempts to resolve such ambiguity. As such, the ambiguity happens because of inadequate or conflicting media reports resolved by complete information subsequently delivered by the media to their audiences. It is in this position when the media's role in ambiguity creation and resolution is relatively easy to see. According to Puiu et al., (2015), cognitive effects include; overcoming the uncertainty; forming the attitude; defining priorities; opinion subject expansion; and clarifying the value system. Likewise, Ball-Rokeach \& DeFleur, (1976) concludes that the cognitive effects of mass media center on attitude formation, expansion of peoples' systems of beliefs and value clarification.

\subsubsection{Affective Effects}

The affective effect is an emotional reaction to indirect information which can arouse strong feelings towards the representation of some social groups which can make people insensible to violence (cruelty) by means of 
excessive display of corresponding materials (Puiu et al., 2015). The impact of media messages on an audience's feelings and emotional responses is one of kind of effects. Almost all media effects could be explored in terms of their affective dimensions, as it is very difficult to envision the cognitive effect of attitude formation without accompanying affective effects. Sometimes the affective element of attitude formation can have serious social consequences.

In periods of intense social conflict the police, for example, may form a number of attitudes from media characterizations about groups with which they have to deal. If media-derived attitudes contain affective elements, such as anger, hostility, and frustration, it may retard the ability of the police to keep their cool when the encounter actually comes. Affective effects are as well associated with morale and alienation, which serve as the kinds of alterations in audience affect that can result from media messages. Puiu et al., (2015) also proposed that people who rely on mass media systems as a primary source of information about their groups and categories can, thus, experience changes in morale and level of alienation when there are notable changes in the quantity or quality of the information delivered by the media about those collectives.

\subsubsection{Behavioral Effects}

Behavioral effects expressed by accepting the new course of actions or by refusing the former one. All these effects influence only those people who rely on the data given by the mass media (Puiu et al., 2015). Behavioral effects described by overt action, which is the kind of effect that most people are most interested in. Where there are changes in attitude, belief and affective states are interesting, but it is the degree, to which they influence overt action that makes them important. Under this study, the concept of activation and de-activation considered as pertinent effects of media messages on behavior. Activation refers to instances in which audience members do something that they would not otherwise have done because of receiving media messages. In this respect, activation may be the product of elaborate cognitive or affective effects. For example, people may engage in issue formation or issue resolution because of the attitudes they have formed and the feelings they have developed (Ball-Rokeach \& DeFleur, 1976). On the other hand, deactivation or what people would have done, but which they do not do because of media messages can be as important as what they activated to do.

To summarize, based on the dependency theory of mass media effect, this research takes the point that, the extent of the media's influence related to the degree of dependence of individuals and social systems on the media. Dependency theory conceives of dependency as a relationship in which the fulfillment of one party's needs and goals is reliant on the resources of another party. Thus, the focus of the theory is the relationship between media and audiences.

While one might learn about possible, desirable behaviors from observing others on rape and sexual violence, Bandura (1997) supported that those behaviors not enacted unless an individual possesses the selfefficacy to do so. Self-efficacy beliefs are judgments that individuals hold about their capabilities to perform a behavior at designated levels. Importantly, Bandura said, "people's level of motivation, affective states, and actions are based more on what they believe than on what is objectively true". For this reason, self-efficacy beliefs are better predictors of people's accomplishments than their previous attainments, knowledge, or skills as such beliefs are associated with goal-related effort, determination, and tolerance in the face of adversity. Selfefficacy beliefs are sensitive to contextual factors, such as the regulation of one's motivation, thought processes, affective states, actions, or environmental conditions. These beliefs are often associated with outcome expectancies. More specifically, self-efficacy helps foster the outcome one expects: confident people anticipate successful outcomes, whereas the opposite is true of those lacking confidence.

The important issues of self-efficacy beliefs in the generation of behavior, it is very important to consider how such beliefs might develop. In fact, there appear to be four sources of information that help to form self-efficacy beliefs. The most influential source is mastery experience, in which the formation of self-efficacy beliefs is intuitive: individuals engage in activities, interpret the results of their behavior, and use their interpretations to develop beliefs about their capability to engage in subsequent activities. Outcomes interpreted as successful raise self-efficacy; those interpreted as failures lower it. People can measure their self-efficacy by the physiological and emotional states, anxiety, stress, and arousal that they experience as they contemplate an action. Strong emotional reactions to a task, like excitement or fear, provide cues about the expected success or failure of the outcome. Focusing on the negative physiological signal, negative thoughts and fears can not only lower self-efficacy perception but also they can also trigger additional stress that contributes to inadequate performance. Thus, one way to raise self-efficacy beliefs is to improve physical and emotional well-being and reduce negative emotional states. 
Further, because individuals have the capability to modify their own thinking and feeling, enhanced self-efficacy beliefs can influence the physiological states themselves. Based on the selection, integration, interpretation, and recollection of information from these four sources of information about self-efficacy, as well as the rules employed for weighting and integrating them, self-efficacy beliefs ultimately formed.

\section{Methodology}

Methodology is the process of researcher used to collect information and data for the purpose of this study. In this case, information collected, analyzed and research processes and procedures based on the role and effect of mass media on rape and sexual violence against women and girls in South Kivu in DRC. This study employed qualitative research design which involved qualitative method. The qualitative information involved data collection through semi-structured interviews and focus group discussions. This design helped to collect and analyze qualitative data through interview. The approach was effective in capturing different opinions of participants, therefore help to present and discuss rich and meaningful findings. Interview guide administered in French and Lingala, and translated in English language.

While interview guide and Focus group discussion depended on the ability and fluent language of the participants, whether French, English, Lingala, and or Swahili. For the focus group discussion, participants were divided depending on the available number, age, and location. In this case, participants, especially community members and Military soldiers, journalists, government officials were divided into groups four groups each comprising twelve participants. Focus Group method sought efficient and convenient as it allowed the views of the members obtained at the same time and quickly.

The participants consisted of 170 selected interviews grouped as, rape and sexual violence victims (women and girls), government officials, community members, Military and Mai Mai rebels, hospital doctors, nurses, religious leaders, journalist, civil, international organizations.

\section{Findings}

The interview results was conducted by the main research questions, participants asked to state ,what are the cognitive ,affective ,and behavioral effects and on rape and sexual violence against women and girls in Southern Kivu These question formed the interview questions asked to the participants. In fact, each interview question considered as a general category of the prior theme. Findings from within the case study begin with a brief introduction of each main participant's category. Afterward, an analysis of each interviewee responses based on research questions in a particular order followed. For the purpose of this study, no individual name of any participant was mentioned. Besides, participants insisted not to mention their names.

\section{The cognitive, affective, and behavioral effect of mass media on rape and sexual violence against girls and women}

The question of this research was to explore how different people perceive cognitive, affective and behavioral effects of mass media on rape and sexual violence against women and girls in South Kivu in DRC. Participants participated effectively in the survey by comprehensively stating the effects that mass media has towards the incidents. The table summarizes the effects of mass media on rape and sexual violence against women and girls. 
Table 1: What are the cognitive, affective, and behavioral effect of mass media on rape and sexual violence against women and girls in South Kivu?

\begin{tabular}{|c|c|c|c|c|c|c|c|c|c|}
\hline $\begin{array}{l}\text { Mass } \\
\text { Media } \\
\text { Effect }\end{array}$ & Opinion & G/Officials & Journalists & $\begin{array}{c}\text { Religious } \\
\text { Leaders }\end{array}$ & I/Organizations & Victims & Doctors & $\begin{array}{c}\text { Community } \\
\text { Members }\end{array}$ & Total \\
\hline \multirow[t]{3}{*}{ Cognitive } & $\begin{array}{l}\text { Media reporting has been used } \\
\text { as a tool to help activists and } \\
\text { governments raise awareness } \\
\text { and implement programs on the } \\
\text { issues of rape and sexual } \\
\text { violence in the community }\end{array}$ & 18 & 12 & 8 & 4 & 6 & 5 & 19 & 72 \\
\hline & $\begin{array}{l}\text { Mass Media have been } \\
\text { projecting the means to combat } \\
\text { incidents of rape and sexual } \\
\text { violence in DRC }\end{array}$ & 17 & 9 & 5 & 5 & 7 & 4 & 16 & 63 \\
\hline & $\begin{array}{l}\text { Mass Media have been } \\
\text { projecting the means to combat } \\
\text { incidents of rape and sexual } \\
\text { violence in DRC }\end{array}$ & 17 & 9 & 5 & 5 & 7 & 4 & 16 & 63 \\
\hline \multirow[t]{2}{*}{ Affective } & $\begin{array}{l}\text { Mass Media has been creating } \\
\text { awareness and brought courage } \\
\text { against the victims of rape and } \\
\text { sexual violence on how to cope } \\
\text { with the effects }\end{array}$ & 13 & 13 & 6 & 4 & 8 & 8 & 18 & 66 \\
\hline & $\begin{array}{l}\text { Some Media incorporate images } \\
\text { that convey destructive } \\
\text { messages causing more trauma } \\
\text { and disinterest among the } \\
\text { victims }\end{array}$ & 10 & 12 & 6 & 6 & 9 & 5 & 9 & 57 \\
\hline \multirow[t]{2}{*}{ Behavioral } & $\begin{array}{l}\text { Mass Media has been raising } \\
\text { awareness among the } \\
\text { community to protect victims of } \\
\text { rape and sexual violence against } \\
\text { the traumas and denials }\end{array}$ & 16 & 14 & 7 & 5 & 7 & 5 & 13 & 67 \\
\hline & $\begin{array}{l}\text { News coverage about rape and } \\
\text { sexual violence against women } \\
\text { has often been sensational, } \\
\text { exploitative, and lacking in } \\
\text { serious analysis of the } \\
\text { prevalence hence bring no } \\
\text { significant impact on the fight }\end{array}$ & 9 & 14 & 5 & 3 & 3 & 6 & 14 & 54 \\
\hline
\end{tabular}

From the findings, $72(50 \%)$ participants stated that media reporting has been used as a tool to help activists and governments raise awareness and implement programs on the issues of rape and sexual violence in the community. 63(43.8\%) stated that mass media have been projecting the means to combat incidents of rape and sexual violence in DRC. Mass media has been creating awareness and brought courage against the victims of rape and sexual violence on how to cope with the effects was stated by $66(45.8 \%)$. In addition, mass media have been raising awareness among the community to protect victims of rape and sexual violence against the traumas and denials stated by $67(46.5 \%)$. On the other hand, 54(37.5\%) stated that news coverage about rape and sexual violence against women and girls has often been sensational, exploitative, and lacking in serious analysis of the prevalence hence bring no significant impact on the fight. 37(25.7\%) participants stated that some media incorporate images that convey destructive messages causing more trauma and disinterest against the victims. Mass media have been able to offer the audience a prior context in the rape and sexual violence against girls and women stated by $40(27.8 \%)$. Media messages fuel anger on armed forces and therefore prompted more rapes was stated by $39(27 \%)$. Mass media are not effective in reporting issues of sexual violence and rape in DRC was stated by $35(24.3 \%)$. Moreover, mass media has no significant impact because they are selective on what to report regarding incidents of rape and sexual violence due to fear of being attacked by armed forces was indicated by $32(22.2 \%)$ participants.

From the findings, there persist mixed perceptions against participants on the effect of mass media on rape and sexual violence against women and girls in DRC. Some mass media has a positive effect on the incidents, and others believe that mass media have no significant effect on rape and sexual violence. On a negative side, participants feel that mass media have been a catalyst to incidents of rape and sexual violence. As much as they report, they provoke the anger of armed forces to do more rape and sexual violence acts. Also, 
mass media due to fear of being arrested or kidnapped by armed forces, they are very selective in what to report regarding the incidents. It is as well obvious that in some cases the victims do not trust mass media since they contain nudity massages, which promote denial and traumatic conditions to them.

\section{Conclusion}

The main objective of this study was, aimed to explore how different people perceive the roles and effects of mass media on rape and sexual violence against women and girls in South Kivu, which covered the research questions, what are the cognitive, affective and behavioral effects of mass media on rape and sexual violence against women and girls in Southern Kivu. According to the findings, mass media identified in numerous ways as a priority area for action on preventing violence against women and girls in DRC. Apparently, mass media in whatever new media forms and information media perceived to be effective in shaping the public discourse because they report on current events and provide a framework for their interpretation. Although news media audiences are not simply passive recipients of information, who or what is selected to appear in the news and how those individuals and events are portrayed can have a profound influence on people's attitudes, beliefs, and behaviors. However, improving the way mass media engage on the issue is one of the key aspect features as a priority area in primary prevention because of its potential influence and effect on public understanding rape and sexual violence against women and girls. Despite a vast repository of research mass media influence, there are no simple mechanisms to explain how or why audiences influenced by what they see, read and hear in the news. Rather, the media effect conceptualized as a complex process involving multiple players: sources, journalists, editors, and audiences. Besides, unquestionably, the way information is structured can increase public understanding rape and sexual violence against women and girls, more importantly, challenge its place in society and prevent its pathological effects.

\section{Reference}

Ball-Rokeach, Sandra J, \& DeFleur, Melvin L. (1976). A dependency model of mass-media effects. Communication Research, 3(1), 3-21.

Bell, Baillie. (2016). the Wartime Rape Narrative in the Democratic Republic of the Congo. Universite d'Ottawa/University of Ottawa.

Bertot, John Carlo, Jaeger, Paul T, \& Hansen, Derek. (2012). the impact of polices on government social media usage: Issues, challenges, and recommendations. Government information quarterly, 29(1), 30-40.

Bhattacharya, Haimanti. (2016). Mass media exposure and attitude towards spousal violence in India. The Social Science Journal, 53(4), 398-416.

Brown, Carly. (2011). Rape as a weapon of war in the Democratic Republic of the Congo.

Bryant, Jennings, \& Zillmann, Dolf. (2009). A retrospective and prospective look at media effects. The Sage handbook of media processes and effects, 9-17.

Carll, Elizabeth K. (2005). Violence and women: News coverage of victims and perpetrators.

Domingo, Headquarters-Pilar, Wild, Liberia-Leni, Brown, Caroline Bowah, Jackson, Afghanistan-Ashley, \& Mosel, Haiti-Irina. (2014). the contribution of UN women to increasing women's leadership and participation in peace and security and in humanitarian response. Women.

Domingo, Pilar, Holmes, Rebecca, Menocal, Alina Rocha, \& Jones, Nicola. (2013). Assessment of the evidence of links between gender equality, peacebuilding and statebuilding. Overseas Development Institute (December 2013), 16.

Egbo, Godwin Chijioke. (2012). An evaluation of newspaper coverage of sexual violence against women and children in selected nigerian newspapers.

Farr, K. (2010). No Escape: Sexual Violence against Women and Girls in Central and Eastern African Armed Conflicts. Deportate, Esuli, Profughe, 13-14.

Graber, D.A., \& Dunaway, J. (2017). Mass media and American politics: Cq Press.

Hansen, D., Shneiderman, B., \& Smith, M.A. (2010). Analyzing social media networks with NodeXL: Insights from a connected world: Morgan Kaufmann.

Hu, Haibo, \& Zhu, Jonathan JH. (2017). Social networks, mass media and public opinions. Journal of Economic Interaction and Coordination, 1-19.

Imtihani, Najih. (2014). The Mass-media Role in Conflict Resolution (A Case Study of Kompas Daily Coverage on Aceh Conflict 2003-2005). Procedia Environmental Sciences, 20, 451-458.

Iyengar, S. (1991). Is Anyone Responsible? How Television News Frames Political Issues. Chicago: Univ: Chicago Press. 
Johnson, Kirsten, Scott, Jennifer, Rughita, Bigy, Kisielewski, Michael, Asher, Jana, Ong, Ricardo, \& Lawry, Lynn. (2010). Association of sexual violence and human rights violations with physical and mental health in territories of the Eastern Democratic Republic of the Congo. Jama, 304(5), 553-562.

Jones, Nicola, Cooper, Janice, Presler-Marshall, Elizabeth, \& Walker, David. (2014). The fallout of rape as a weapon of war: London: Overseas Development Institute.

Leatherman, Janie. (2011). Sexual violence and armed conflict: Polity.

Loges, W. E. (1994). Canaries in the coal mine: Perceptions of threat and media system dependency relations. Communication Research, 21(1), 5-23.

Merskin, D. (1999). Media dependency theory: Origins and directions. Mass media, social control, and social change, 77-98.

McCombs, Maxwell, \& Reynolds, Amy. (2009). How the news shapes our civic agenda. Media effects: Advances in theory and research, 1-16.

McLeod, J. M., Kosicki, G. M., \& Pan, Z. (1991). On understanding and misunderstanding media effects. Mass media and society, 235-266

McQuail, Denis. (1994). Mass communication: Wiley Online Library.

McQuail, Denis. (2010). McQuail's mass communication theory: Sage publications.

Mukwege, Denis Mukengere, \& Nangini, Cathy. (2009). Rape with extreme violence: the new pathology in South Kivu, Democratic Republic of Congo. PLoS Med, 6(12), e1000204.

Ohambe, Marie C, Galloy, Martine R, \& Sow, Ndeye. (2004). Women's Bodies as a Battleground: Sexual Violence against Women and Girls during the War in the Democratic Republic of Congo: South Kivu (1996-2003).

Patwardhan, P., \& Ramaprasad, J. (2005, May). Internet dependency relations and online activity exposure, involvement and satisfaction: A study of American and Indian internet users. In annual convention of the International Communication Association, New York. Retrieved March (Vol. 13, No. 2009, pp. 4-1).

Potter, W James. (2011). Conceptualizing mass media effect. Journal of communication, 61(5), 896-915.

Potter, W James. (2012). Media effects: Sage.

Puiu, Yulia Valerievna, Puiu, Daria Anatolevna, Sablin, Ilia Vladimirovich, Georgieva, Elena Savova, \& Bykov, Aleksey Yuryevich. (2015). Conceptual Framework of Mass Media Manipulative Models Forming. International Review of Management and Marketing, 5(1S).

Scheufele, Dietram A, \& Tewksbury, David. (2007). Framing, agenda setting, and priming: The evolution of three media effects models. Journal of communication, 57(1), 9-20.

Shapiro, Michael A, \& Chock, T Makana. (2004). Media dependency and perceived reality of fiction and news. J. Broad. \& Elec. Media, 48, 675. ]

Schultz, Tanjev. (2000). Mass media and the concept of interactivity: an exploratory study of online forums and reader email. Media, culture \& society, 22(2), 205-221.

Yildirim, Tuba Pinar. (2012). THE IMPACT OF ADVERTISING AND USER-GENERATED CONTENT ON MEDIA BIAS. University of Pittsburgh. 